\title{
Introduction to "Unintended Consequences: The U.S. Postal Service Conundrum of Service, Business, Labor, and Politics"
}

\author{
Victor G. Devinatz ${ }^{1}$
}

Published online: 17 March 2021

(C) The Author(s), under exclusive licence to Springer Science+Business Media, LLC, part of Springer Nature 2021

The 2020 United States Postal Service (USPS) crisis, which began in late spring 2020, can be characterized as the implementation of various measures that resulted in logjams and delays in mail delivery by the USPS. The problems occurred largely from modifications made by Postmaster General Louis DeJoy shortly after he assumed his leadership role in mid-June 2020. Given the COVID-19 pandemic and the subsequent financial fallout, the mail delays resulted in significant negative effects for postal customers. Moreover, given that 2020 was a US presidential election year, there was speculation that mail delays were deliberately created to aid President Trump in his reelection bid rather than solely occurring due to the restructuring of postal operations. It had been reported that DeJoy backed Trump and had financially contributed to him. Trump had opposed providing the USPS with emergency funding which appeared to be an attempt to limit voting by mail in the 2020 elections. It was contended that Trump believed that citizens who were more likely to vote by mail were those who would not cast ballots for him.

In this excellent, insightful and timely article, Dr. Philip F. Rubio, Professor of History at North Carolina A\&T State University, discusses the 2020 turbulence engulfing the U.S. Postal Service (USPS), a situation unseen in half a century when over 200,000 employees struck the US Post Office Department (USPOD) in March 1970. The strike resulted in the passage of the Postal Reorganization Act in the summer of 1970 which created the USPS in July 1971. While some might believe the 2020 crisis emanated from the COVID-19 pandemic, it dates to the postal financial crisis in 2009. Rubio contends that these conflicts are due to "unintended consequences" of the USPS being established as a mixture between a business and a government agency. Moreover, Rubio argues that in the ongoing debates over whether the USPS should be privatized, postal workers' rights are often neglected. He states that the history of this debate goes back to the USPOD's management of labor when it utilized "business methods" involving the implementation of strict discipline, contingent workers to slash costs while fomenting racial divisions among postal workers.

If any of the journal's readers are interested in responding to any essays published in the "Perspectives" Section or would like to write articles on any topics in the field of employee relations, please do not hesitate to contact me with your proposal. I welcome

Victor G. Devinatz

vgdevin@ilstu.edu

1 Department of Management \& Quantitative Methods, Illinois State University, Normal, IL 61790-5580, USA 
both practitioner-based and scholarly-based articles written from any one of a variety of theoretical perspectives. I hope that you enjoy this article and find it most illuminating.

Victor G. Devinatz, Editor of "Perspectives" Section

Department of Management \& Quantitative Methods

Illinois State University

Normal, Illinois 61790-5580

Publisher's Note Springer Nature remains neutral with regard to jurisdictional claims in published maps and institutional affiliations. 